\title{
TINGKAT PEMAHAMAN SISWA PADA ATLETIK NOMOR LARI KELAS XI SMK INSAN SEMPURNA PENDIDIKAN KARAWANG
}

\author{
Fitri Himalaya ${ }^{1}$, Akhmad Dimyati $^{2}$, Irfan Zinat Achmad $^{3}$ \\ Program Studi Pendidikan Jasmani Kesehatan Dan Rekreasi \\ Fakultas Keguruan Dan Ilmu Pendidikan, Universitas Singaperbangsa Karawang ${ }^{123}$ \\ $\underline{\text { Fitrihimalaya97@gmail.com }}^{1} \underline{\text { akhmad.dimyati@ fkip.unsika.ac.id }}^{2}$, $^{\text {irfan.za@ @kip.unsika.ac.id }}{ }^{3}$
}

\begin{abstract}
ABSTRAK
Penelitian ini bertujuan untuk mengetahui seberapa besar tingkat pemahaman siswa pada atletik nomor lari kelas XI SMK Insan Sempurna Pendidikan Karawang. Penelitian ini merupakan penelitian deskriptif kuantitatif, metode yang digunakan adalah survey study. Teknik pengumpulan data berupa angket menggunakan tes soal pilihan ganda. Populasi yang digunakan adalah seluruh siswa kelas XI SMK Insan Sempurna Pendidikan Karawang yang berjumlah 92 siswa. Sampel yang digunakan dalam penelitian ini sebanyak 92 siswa dengan teknik pengambilan sampel yaitu sampel jenuh. Data pada penelitia dianalisis dengan menggunakan statistik deskriptif dengan presentase. Hasil penelitian menunjukan tingkat pemahaman siswa pada atletik nomor lari kelas XI SMK Insan Sempurna Pendidikan Karawang secara keseluruhan beradapada kategori "Cukup" dengan jumlah 33 siswa dan presentase sebesar (36\%).
\end{abstract}

Kata Kunci: Tingkat Pemahaman, Atletik Nomor Lari.

\begin{abstract}
This study aims to determine how much the level of understanding of students in the athletic run number class XI SMK Insan Sempurna Pendidikan Karawang. This research is a descriptive quantitative research, the method used is a survey study. The data collection technique was in the form of a questionnaire using multiple choice test questions. The population used was all students of class XI SMK Insan Sempurna Pendidikan Karawang, totaling 92 students. The sample used in this study were 92 students with the sampling technique, namely saturated samples. The data in the research were analyzed using descriptive statistics with percentages. The results showed the level of understanding of students in athletics running number class XI SMK Insan Sempurna Pendidikan Karawang as a whole was in the "Enough" category with a total of 33 students and a percentage of (36\%).
\end{abstract}

Keywords: Comprehension Level, Athletics Number Running.

Dipublikasikan Oleh :

UPT Publikasi dan Pengelolaan Jurnal

Universitas Islam Kalimantan Muhammad Arsyad Al-Banjari Banjarmasin 


\section{PENDAHULUAN}

Pendidikan berasal dari kata "didik", lalu kata ini mendapat awalan "me" sehingga menjadi "mendidik" artinya, memelihara dan memberi latihan. Dalam memelihara dan memberi latihan diperlukan adanya ajaran, tuntunan, dan pimpinan mengenai akhlak dan kecerdasan pikiran (Syah, 2010:10), diperkuat oleh penelitian Gunawan, (2020:156) yang mengemukakan bahwa proses pendidikan merupakan terjadinya interaksi antara guru dengan siswa, guna siswa dapat membentuk karakter yang lebih unggul, lalu penelitian oleh penelitian Pambudi, Winarno \& Dwiyogo, (2019:111) menyatakan bahwa Peran pendidikan sangatlah penting dalam kehidupan manusia, generasi muda sekarang yang mengemban ilmu pendidikan disiapkan untuk terampil dalam dunia pendidikan dan mampu mengubah perubahan kehidupan yang lebih baik melalui pendidikan. Sehingga dapat disimpulkan bahwa pendidikan adalah usaha sadar dan terencana untuk mewujudkan suasana belajar dan proses pembelajaran agar peserta didik secara aktif mengembangkan potensi dirinya untuk memiliki kekuatan spiritual keagamaan, pengendalian diri, kepribadian, kecerdasan, akhlak mulia, serta ketrampilan yang diperlukan dirinya, masyarakat, bangsa dan negara.

Pembelajaran ialah bagian dari pendidikan dan spesifik, proses dimana lingkungan seseorang dengan sengaja dikelola agar dapat memberikan respons terhadap situasi yang spesifik. (Dwiyogo, 2010:3). Selain itu penelitian oleh Pahliwandari, (2016:156) Proses pembelajaran harus mampu menjaga keseimbangan antara peran kognisi dengan peran afeksi (perasaan dan emosi yang lunak), sehingga lulusan pendidikan memiliki kualitas intelektual dan moral kepribadian yang seimbang. Sementara itu Hasan, (2015:183) mengemukakan bahwa Pembelajaran merupakan suatu upaya dalam menciptakan seseorang memperoleh pengetahuan, keterampilan dan sikap oleh.

Pembelajaran pendidikan jasmani (penjas) menjadi suatu proses yang amat penting dalam keseluruhan tahap pendidikan yang ada di sekolah dasar dan sekolah menengah. Dalam proses pembelajaran penjas, guru diharapkan mengajarkan berbagai keterampilan gerak dasar, teknik, permainan dan olahraga, nilai-nilai (sportifitas, jujur, kerjasama, dan lain-lain) serta pembiasaan pola hidup sehat hal ini diperkuat oleh penelitian Rahayu, (2013:62) yang mengemukakan bahwa Pendidikan jasmani merupakan proses melalui aktivitas jasmani, yang dirancang dan disusun secara sistematik guna mengembangkan dan meningkatkan individu secara organik, neuromuskular, perseptual, kognitif, dan emosional, dalam rangka sistem pendidikan nasional. . Lalu penelitian oleh Achmad, (2013:3) Penjas merupakan bagian penting dari keseluruhan proses pendidikan dengan tujuan peningkatan kinerja manusia melalui media kegiatan fisik untuk mengembangkan dan memelihara tubuh manusia. Karena dalam pendidikan jasmani siswa akan dituntun untuk bergerak, karena bergerak merupakan salah satu aspek utama dalam pendidikan jasmani. Pendidikan jasmani mengharuskan siswa bergerak tanpa dibatasi, oleh karena itu Pendidikan jasmani merupakan satu-satunya pelajaran yang diadakan diluar ruangan kelas.

Atletik merupakan salah satu cabang olahraga yang paling kompleks, karena banyak nomor yang dipertandingkan. Selain dari itu gerakan yang terdapat dalam atletik merupakan gerak dasar bagi cabang olahraga lainnya, karena hampir semua cabang olahraga memerlukan kekuatan, kecepatan, kelenturan dan daya tahan oleh karena itu tidaklah berlebihan sejarah mengemukakan bahwa atletik adalah ibu dari semua cabang olahraga. Hal ini diperkuat melalui penelitian Bahagia (2011:4), atletik adalah athletics (bahasa Inggris), athletiek (bahasa Belanda), athletique (bahasa Perancis) atau athletik (bahasa Jerman). Istilahnya mirip sama, namun artinya berbeda dengan arti atletik di Indonesia, yang berarti olahraga yang memperlombakan nomornomor: jalan, lari, lompat dan lempar. Sedangkan Purnomo \& Dapan (2011:1-3), menyatakan bahwa "kata "atletik" berasal dari bahasa Yunani, athlon atau athlum yang berarti lomba atau perlombaan. Sehingga atletik merupakan salah satu mata pelajaran pendidkan jasmani yang wajib diberikan kepada para siswa mulai dari tingkat Sekolah Dasar sampai Sekolah Lanjutan Tingkat Atas, sesuai dengan SK Mendikbud No. 0413/U/87.

Secara umum ruang lingkup pembelajaran atletik di sekolah-sekolah meliputi nomor-nomor lari, lompat, lempar, dan jalan. Pembagian kelompok tersebut adalah sebagai berikut: Nomor lari meliputi: lari jarak pendek, lari jarak menengah, lari jarak jauh, lari estafet, dan lari rintangan meliputi: lari gawang dan halang rintang. Nomor lompat meliputi: lompat jauh, lompat tinggi, lompat jangkit, lompat tinggi galah. Nomor lempar meliputi: tolak peluru, lempar cakram, lempar lembing, lontar martil. Dan nomor jalan meliputi: jalan cepat. Sebagian besar dari nomor-nomor atletik tersebut ada dalam kurikulum pendidikan jasmani kesehatan dan olahraga mulai jenjang Sekolah Dasar sampai Sekolah Lanjutan Tingkat Atas. Berdasarkan penelitian Purnomo \& Dapan (2011:3) menyatakan bahwa nomor-nomor dalam atletik yang sering diperlombakan adalah sebaagai berikut: Nomor jalan, jalan cepat untuk putri,10 atau $20 \mathrm{~km}$, dan putra $20 \mathrm{~km}$ dan $50 \mathrm{~km}$. Nomor lari, ditinjau dari jarak tempuh terdiri atas: lari jarak pendek (sprint) mulai dari $60 \mathrm{~m}$ sampai dengan $400 \mathrm{~m}$, lari jarak menengah (middle distance) $800 \mathrm{~m}$ dan $1500 \mathrm{~m}$, lari jarak jauh (long distance) $3000 \mathrm{~m}$ sampai dengan $42.195 \mathrm{~m}$ (marathon). Nomor lompat tardiri dari: lompat tinggi (high jump), lompat jauh (long jump), lompat jangkit

Dipublikasikan Oleh : 
(triple jump), lompat tinggi gajah (polevoult). Nomor lempar terdiri atas: Tolak peluru (shot put), lempar lembing (javelin throw), lempar cakram (discus throw), lempar martil (hammer).

Lari merupakan suatu langkah yang dipercepat sehingga pada waktu berlari ada kecenderungan badan melayang, yang artinya pada kedua kaki tidak menyentuh tanah sekurang kurangnya satu kaki tetap menyentuh tanah. Dalam nomor lari meliputi: lari jarak pendek, lari jarak menengah, lari jarak jauh, lari estafet, dan lari rintangan meliputi: lari gawang dan halang rintang. Muhtar (2011:12), yang mengemukakan bahwa lari jarak pendek merupakan lari yang menempuh jarak antara 50 sampai $400 \mathrm{~m}$ dengan membutuhkan reaksi dan dorongan, menambah percepatan sampai mencapai kecepatan maksimal dalam waktu beberapa detik untuk sampai digaris finish. Sedangkan Lari jarak menengah adalah olahraga lari yang dilakukan pada lintasan lomba dengan jarak lebih panjang dari lari jarak pendek. Untuk putri jarak pada lari jarak menengah adalah 800 meter, 1500 meter. Sedangkan untuk putra adalah 800 meter, 1500 meter, dan 3000 meter. (Natal, 2018:16). Lalu lari jarak jauh merupakan cabang lari yang memiliki panjang lintasan terjauh yaitu mulai dari 3000 meter hingga 10.000 meter. Selanjutnya Lari estafet dapat juga disebut sebagai lari beregu, yang mana masing-masing regu terdiri dari empat anggota (pelari). Ciri khas dari lari estafet adalah adanya tongkat yang harus dibawa (dipegang) oleh pelari pertama untuk diberikan kepada pelari kedua, dari pelari kedua ke pelari ketiga, dan terakhir diberikan kepada pelari keempat. Dan Lari gawang adalah lari cepat (sprint) dengan melewati gawang sebanyak 10 buah gawang dengan ketinggian tertentu dan dipasang di dalam lintasan.

Seorang guru penjas dalam melakukan pembelajaran sebaiknya harus dapat melihat terlebih dahulu seberapa paham semua siswa dalam pembelajaran sehingga proses pembelajaran dapat dilakukan dengan baik dan yang paling penting tidak terjadi kecelakaan. (Gunawan, 2020:158).lalu penelitian oleh Ulinnuha, (2017:4) Pemahaman (comprehension) merupakan kemampuan seseorang dalam mengerti atau memahami sesuatu setelah sesuatu itu dipahami dan diingat. dengan kata lain, memahami adalah mengerti atau dapat menjelaskan apa yang telah diingat dan telah dipelajari dari sesuatu yang telah di dapatkan. Selanjutnya penelitian Putro, (2019:51) yang menyatakan bahwa pemahaman adalah suatu proses memahami, menanamkan dan memahamkan. Jadi, seorang siswa dikatakan memahami sesuatu apabila siswa tersebut dapat memberikan penjelasan atau memberi uraian yang lebih rinci tentang hal yang siswa pelajari dengan menggunakan bahasanya sendiri.

Berdasarkan hasil wawancara yang dilakukan peneliti kepada guru di SMK Insan Sempurna Pendidikan Karawang dalam pembelajaran pendidikan jasmani hanya memberikan beberapa nomor atletik. Pada proses pembelajaran atletik menunjukan bahwa masih kurang penyediaan sarana dan prasarana pendidikan jasmani seperti lapangan dan peralatan yang kurang memadai, dan tetap menjalankan pembelajaran pendidikan jasmani disekolah dengan peralatan yang seadanya sehingga dalam proses pembelajaran belum berjalan dengan baik. Dari hasil wawancara peneliti kepada guru, saat pembelajaran ketika siswa diberikan pertanyaan mengenai atletik terdapat siswa yang kurang paham tentang materi pembelajaran yang diberikan oleh guru, dikarenakan terdapat siswa yang tidak mendengarkan penjelasan guru pada saat materi. Dan pada saat pembelajaran penjas pentingnya pengetahuan dasar tentang materi yang diajarkan sehingga apa yang diketahui oleh siswa bisa diterapkan dengan benar pada saat praktik dilapangan. Hal tersebut diperkuat oleh penelitian terdahulu Zulfikar, (2019) yang berjudul "Tingkat Pengetahuan Siswa Kelas VIII Terhadap Pembelajaran Lari Jarak Pendek Di SMP Negeri 5 Depok Sleman Tahun Ajaran 2018/2019" Hasil penelitian menunjukkan bahwa tingkat pengetahuan siswa kelas VIII tentang pembelajaran lari jarak pendek di SMP Negeri 5 Depok Sleman tahun ajaran 2018/2019 yaitu sebanyak 92 siswa kategori baik (17,4 \%), kategori cukup (66,3 \%), dan kategori kurang $(16,3 \%)$. Tentunya proses pembelajaran menjadi bagian penting dan berpengaruh pada hasil pemahaman siswa dalam aktivitas atletik. Berdasarkan penelitian terdahulu, yang menjadi perbedaan dalam penelitian ini yaitu pertama, Sampel yang digunakan. Kedua, pembaharuan instrumen penelitian yang menyesuaikan rancangan pelaksanaan pembelajaran guru PJOK di SMK Insan Sempurna Karawang.

\title{
METODE
}

Penelitian ini menggunakan metode deskriptif dengan pendekatan kuantitatif melalui penggunaan instrumen survey study untuk mengetahui tingkat pemahaman siswa pada atletik nomor lari kelas xi smk insan sempurna pendidikan karawang.

Adapun Desain dalam penelitian yang dilakukan dalam penelitian ini menggunakan langkah langkah penelitian kuantitatif deskriptif terdiri dari : 1.) Mengidentifikasi adanya permasalahan yang signifikan untuk dipecahkan melalui metode deskriptif, 2.) Membatasi dan merumuskan permasalahan secara jelas, 3.) Menentukan tujuan dan manfaat penelitian, 4.) Melakukan studi pustaka yang berkaitan dengan permasalahan, 5.) Menentukan kerangka berpikir, dan pertanyaan penelitian dan atau hipotesis penelitian, 6.) Mendesain metode penelitian yang hendak digunakan termasuk dalam hal ini menentukan populasi, sampel, teknik sampling, menentukan instrumen, mengumpulkan data, dan menganalisis data, 7.) Mengumpulkan,

\author{
Dipublikasikan Oleh : \\ UPT Publikasi dan Pengelolaan Jurnal \\ Universitas Islam Kalimantan Muhammad Arsyad Al-Banjari Banjarmasin
}


mengorganisasikan, dan menganalisis data dengan menggunakan teknik statistika yang relevan, dan 8.) Membuat laporan penelitian (Gunawan et al., 2020). Berikut ini merupakan kisi-kisi instrumen penelitian.

Tabel 1. Kisi-Kisi Instrumen Tingkat Pemahaman Siswa Pada Atletik Nomor Lari

\begin{tabular}{|c|c|c|c|c|}
\hline Variabel penelitian & Faktor & Indikator & Item & Jumlah \\
\hline \multirow{5}{*}{$\begin{array}{c}\text { Tingkat Pemahaman Siswa Pada } \\
\text { Atletik Nomor Lari Kelas XI SMK } \\
\text { Insan Sempurna Pendidikan Karawang }\end{array}$} & Mengingat & $\begin{array}{l}\text { Mengingat hakikat } \\
\text { atletik }\end{array}$ & $\begin{array}{l}1,2,3,4 \\
5,6\end{array}$ & 6 \\
\hline & $\begin{array}{c}\text { Pembelajaran Atletik } \\
\text { Nomor Lari }\end{array}$ & $\begin{array}{l}\text { Mengingat macam- } \\
\text { macam atletik } \\
\text { nomor lari }\end{array}$ & $\begin{array}{l}7,8,9,10 \\
11,12,13 \\
14,15\end{array}$ & 9 \\
\hline & \multirow{3}{*}{$\begin{array}{c}\text { Memahami } \\
\text { Pembelajaran Atletik } \\
\text { Nomor Lari }\end{array}$} & & & \\
\hline & & $\begin{array}{l}\text { Memahami teknik- } \\
\text { teknik lari }\end{array}$ & $\begin{array}{l}16,17,18 \\
19,20,21 \\
22\end{array}$ & 7 \\
\hline & & $\begin{array}{l}\text { Memahami gerakan } \\
\text { dan peraturan nomor } \\
\text { lari }\end{array}$ & $\begin{array}{l}23,24,25 \\
26,27,28 \\
\quad 29,30\end{array}$ & 8 \\
\hline \multicolumn{4}{|c|}{ Jumlah } & 30 \\
\hline
\end{tabular}

Tingkat pemahaman siswa pada atletik nomor lari dipengaruhi oleh 2 faktor dan 4 indikator, yaitu: 1) Faktor mengingat pembelajaran atletik nomor lari, yang terdiri dari 2 indikator meliputi : A) indikator mengingat hakikat atletik dan B) Mengingat macam macam atletik nomor lari. 2) Faktor memahami pembelajaran atletik nomor lari, yang terdiri dari 2 indikator meliputi: A) Memahami teknik teknik lari dan B) Memahami peraturan dan nomor lari. Terdapat 30 butir soal pertanyaan (multiple choise). Teknik penilaian (scoring) yang dilakukan pada tes tersebut adalah memberikan skor 1 (satu) pada item jawaban yang benar, dan skor 0 (nol) pada jawaban yang salah. Jika dalam mengerjakan tes tersebut ada item soal yang tidak dijawab atau kosong, maka dalam penilaian, item yang tidak dijawab tersebut tetap diberi nilai 0 (nol).

Sebelum kuisioner digunakan, maka diperlukan uji instrumen berupa uji validitas untuk mengukur ketepatan di setiap butir soal, digunakan teknik produk momen sari karl pearson dengan taraf signifikansi $5 \%$ (Sugiyono, 2013). Butir soal dikatakan valid apabila $r_{\text {hitung }}>r_{\text {tabel }}$, untuk nilai $r_{\text {tabel }}$ dengan responden 20 orang adalah sebesar 0,444. Setelah dilakukan perhitungan dapat diketahui terdapat 3 butir soal yang tidak valid yaitu butir soal nomor 3,5 dan 11. Jadi peneliti hanya memakai 27 butir soal dari total 30 butir soal, Dan dilakukan uji reabilitas dengan menggunakan rumus alpha cronbach dengan taraf signifikansi 5\%, (Arikunto, 2013:211) suatu instrumen dikatakan reliable jika $r_{11}>r_{\text {tabel }}$, hasil uji reabilitas diperoleh nilai $r_{11}=0,847>r_{\text {tabel }}=0,632$ dengan demikian menunjukan angket yang diuji cobakan reliable dan dapat digunakan untuk pengumpulan data penelitian.

Populasi dalam penelitian ini adalah seluruh siswa kelas XI SMK Insan Sempurna Pendidikan Karawang sebanyak 4 kelas dengan jumlah 92 siswa. Teknik pengambilan sampel menggunakan teknik sampel jenuh, penelitian ini mengambil sampel keseluruhan dikarenakan populasi kurang dari 100, (Sudijono, 2012) dan untuk jumlah sampel dalam penelitian ini berjumlah 92 siswa dari 4 kelas. Selanjutnya data disajikan dalam bentuk tabel frekuensi dan kemudian dilakukan pengkategorian serta menyajikan data dalam bentuk histogram. Dalam pengkategorian skor mengunakan lima kategori yaitu, sangat baik, baik, cukup, kurang, dan buruk.

Tabel 2. Norma Pengkategorian

\begin{tabular}{cc}
\hline Interval & Kategori \\
\hline $\mathrm{M}+1,5 \mathrm{SD} \leq \mathrm{X}$ & Sangat baik \\
$\mathrm{M}+0,5 \mathrm{SD} \leq \mathrm{X}<\mathrm{M}+1,5 \mathrm{SD}$ & Baik \\
$\mathrm{M}-0,5 \mathrm{SD} \leq \mathrm{X}<\mathrm{M}+0,5 \mathrm{SD}$ & Cukup \\
$\mathrm{M}-1,5 \mathrm{SD} \leq \mathrm{X}<\mathrm{M}-0,5 \mathrm{SD}$ & Kurang \\
$\mathrm{X}<\mathrm{M}-1,5 \mathrm{SD}$ & Buruk \\
\hline
\end{tabular}

Dipublikasikan Oleh :

UPT Publikasi dan Pengelolaan Jurnal

Universitas Islam Kalimantan Muhammad Arsyad Al-Banjari Banjarmasin 
Keterangan.

$\begin{array}{ll}\mathrm{X} & \text { : Skor yang diperoleh } \\ \mathrm{SD} & \text { : standar deviasi } \\ \mathrm{M} & \text { : mean (rata-rata) }\end{array}$

Data disajikan dalam bentuk frekuensi relatif yang yang dituangkan dalam bentuk angka prosentase. Untuk memperoleh persentase digunakan rumus:

Keterangan:

$\mathbf{p}=\mathbf{f} / \mathbf{N} \times 100 \%$

$\begin{array}{ll}\mathrm{P} & \text { : angka persentase } \\ \mathrm{F} & \text { : frekuensi } \\ \mathrm{N} & \text { : jumlah subjek/ responden }\end{array}$

\section{HASIL DAN PEMBAHASAN}

Berdasarkan hasil penelitian yang telah diperoleh dilapangan mengenai Tingkat Pemahaman Aktivitas Atletik Nomor Lari Pada Siswa Kelas XI SMK Insan Sempurna Pendidikan Karawang, Peneliti akan mendeskripsikan dan menganalisis data tersebut menggunakan metode deskriptif dengan pendekatan kuantitatif. Untuk memperoleh data dalam penelitian ini, peneliti menggunakan instrumen survey study menggunakan kuisioner berupa soal pilihan ganda (multiple choise). Dari hasil penelitian yang diperoleh, tingkat pemahaman siswa pada atletik nomor lari kelas XI di kategorikan menjadi 5 kategori yaitu, kategori sangat baik, baik, cukup, kurang dan buruk. Sehingga statistic deskriptif mengenai tingkat pemahaman siswa pada atletik nomor lari kelas XI dapat dilihat pada table berikut.

Tabel 3. Hasil Statistik Deskriptif Penelitian

\begin{tabular}{cccccccc}
\hline $\begin{array}{c}\text { Keteranga } \\
\mathrm{n}\end{array}$ & $\begin{array}{c}\text { Keseluruha } \\
\mathrm{n}\end{array}$ & $\begin{array}{c}\text { Mengingat } \\
\text { Pembelajara } \\
\text { n Atletik } \\
\text { Nomor Lari }\end{array}$ & $\begin{array}{c}\text { Menginga } \\
\text { t Hakikat } \\
\text { Atletik }\end{array}$ & $\begin{array}{c}\text { Menginga } \\
\text { t Macam- } \\
\text { Macam } \\
\text { Atletik } \\
\text { Nomor } \\
\text { Lari }\end{array}$ & $\begin{array}{c}\text { Memahami } \\
\text { Pembelajara } \\
\text { n Atletik } \\
\text { Nomor Lari }\end{array}$ & $\begin{array}{c}\text { Memaham } \\
\text { i Teknik } \\
\text { Lari }\end{array}$ & $\begin{array}{c}\text { Memaham } \\
\text { i Gerakan } \\
\text { dan } \\
\text { Peraturan } \\
\text { Lari }\end{array}$ \\
\hline Mean & 19.48 & 81.70 & 91.85 & 76.63 & 64.5 & 63.0 & 65.76 \\
Standar & 5.24 & 19.62 & 20.00 & 22.86 & 22.3 & 23.4 & 26.33 \\
$\begin{array}{c}\text { Deviasi } \\
\text { Median }\end{array}$ & 20.5 & 83.33 & 100.00 & 81.25 & 66.7 & 71.4 & 62.50 \\
Range & 19 & 83.33 & 100.00 & 75 & 93.3 & 100.0 & 100.00 \\
Minimum & 8 & 16.67 & 0.00 & 25 & 6.7 & 0.0 & 0.00 \\
Maximum & 27 & 100.00 & 100.00 & 100 & 100.0 & 100.0 & 100.00 \\
\hline
\end{tabular}

Hasil analisis data statistic penelitian secara keseluruhan memperoleh nilai mean sebesar 19,48, standar deviasi sebesar 5,24, Median sebesar 20,5, range sebesar19, nilai minimum sebesar 8, dan nilai maksimal sebesar 27. Kemudian hasil data statistic secara ideal dimasukan kedalam table distribusi frekuensi, maka data tingkat pemahaman siswa pada atletik kelas XI SMK Insan Sempurna Pendidikan Karawang sebagai berikut.

Tabel 4. Tingkat Pemahaman Siswa Pada Atletik Nomor Lari Kelas XI SMK Insan Sempurna Pendidikan Karawang

\begin{tabular}{ccccccc}
\hline No & & Interval & & Kategori & Frekuensi & $\%$ \\
\hline 1 & & $\mathrm{X}>$ & 101.25 & Sangat Baik & 0 & $0 \%$ \\
2 & 81.85 & $<\mathrm{X}<$ & 101.25 & Baik & 32 & $35 \%$ \\
3 & 62.44 & $<\mathrm{X}<$ & 81.85 & Cukup & 33 & $36 \%$ \\
4 & 43.03 & $<\mathrm{X}<$ & 62.44 & Kurang & 19 & $21 \%$ \\
5 & & $\mathrm{X}<$ & 43.03 & Buruk & 8 & $9 \%$ \\
\hline
\end{tabular}

Dipublikasikan Oleh :

UPT Publikasi dan Pengelolaan Jurnal

Universitas Islam Kalimantan Muhammad Arsyad Al-Banjari Banjarmasin 
Berdasarkan tabel tersebut dapat dijelaskan bahwa secara keseluruhan tingkat pemahaman siswa pada atletik nomor lari kelas xi smk insan sempurna pendidikan karawang berkategori "cukup" dengan jumlah 33 siswa (36\%), yang tidak jauh berbeda dengan kategori baik yang berjumlah 32 siswa (35\%). Apabila digambarkan dalam bentuk diagram batang diperoleh sebagai berikut.

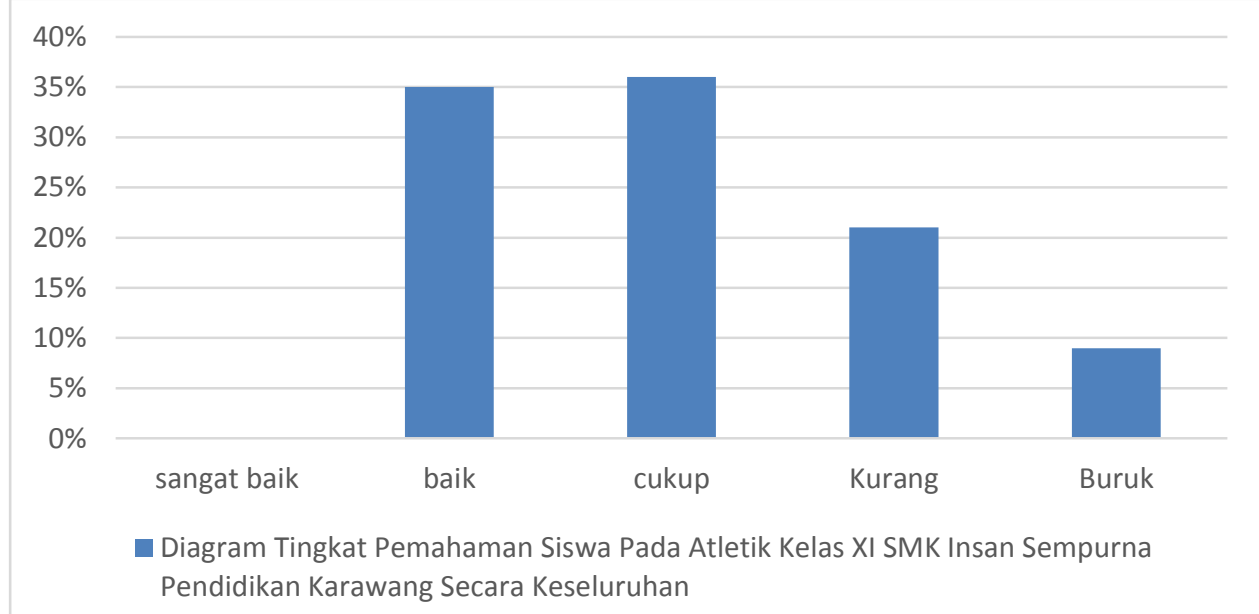

\section{Gambar 1. Diagram Tingkat Pemahaman Siswa Pada Atletik Kelas XI SMK Insan Sempurna Pendidikan Karawang Secara Keseluruhan}

\section{Faktor Mengingat Pembelajaran Atletik Nomor Lari}

Dalam instrument penelitian ini terdapat 2 indikator yaitu, mengingat hakikat atletik dan mengingat macam-macam atletik nomor lari. Masing-masing indikator dijabarkan melalui beberapa butir pertanyaan, mengingat hakikat atletik 6 pertanyaan, dan mengingat macam-macam atletik nomor lari 9 pertanyaan, tetapi dalam mengingat hakikat atletik 2 butir soal dinyatakan tidak valid, dan dalam mengingat macam-macam atletik nomor lari dinyatakan 1 pertanyaan tidak valid. Berdasarkan hasil penelitian dari faktor mengingat pembelajaran atletik nomor lari diperoleh mean sebesar 81,70, standar deviasi sebesar 19,62, Range sebesar 83,33, median sebesar 83,33, nilai minimum 16,67 dan nilai maximum 100. Dapat dimasukan kedalam tabel distribusi frekuensi sebagai berikut

\begin{tabular}{ccccccc}
\multicolumn{6}{c}{ Tabel 5. Distribusi Frekuensi Faktor Mengingat Pembelajaran Atletik Nomor Lari } \\
\hline no & & Interval & & Kategori & Frekuensi & $\%$ \\
\hline 1 & & $\mathrm{X}>$ & 111.13 & Sangat Baik & 0 & $0 \%$ \\
2 & 91.51 & $<\mathrm{X}<$ & 111.13 & Baik & 44 & $48 \%$ \\
3 & 71.89 & $<\mathrm{X}<$ & 91.51 & Cukup & 21 & $23 \%$ \\
4 & 52.27 & $<\mathrm{X}<$ & 71.89 & Kurang & 20 & $22 \%$ \\
5 & & $\mathrm{X}<$ & 52.27 & Buruk & 7 & $8 \%$
\end{tabular}

Berdasarkan tabel tersebut dapat dijelaskan bahwa secara faktor mengingat pembelajaran atletik tingkat pemahaman siswa pada atletik nomor lari kelas xi smk insan sempurna pendidikan karawang berkategori "cukup" dengan jumlah 44 siswa (48\%). Apabila digambarkan dalam bentuk diagram batang diperoleh sebagai berikut. 


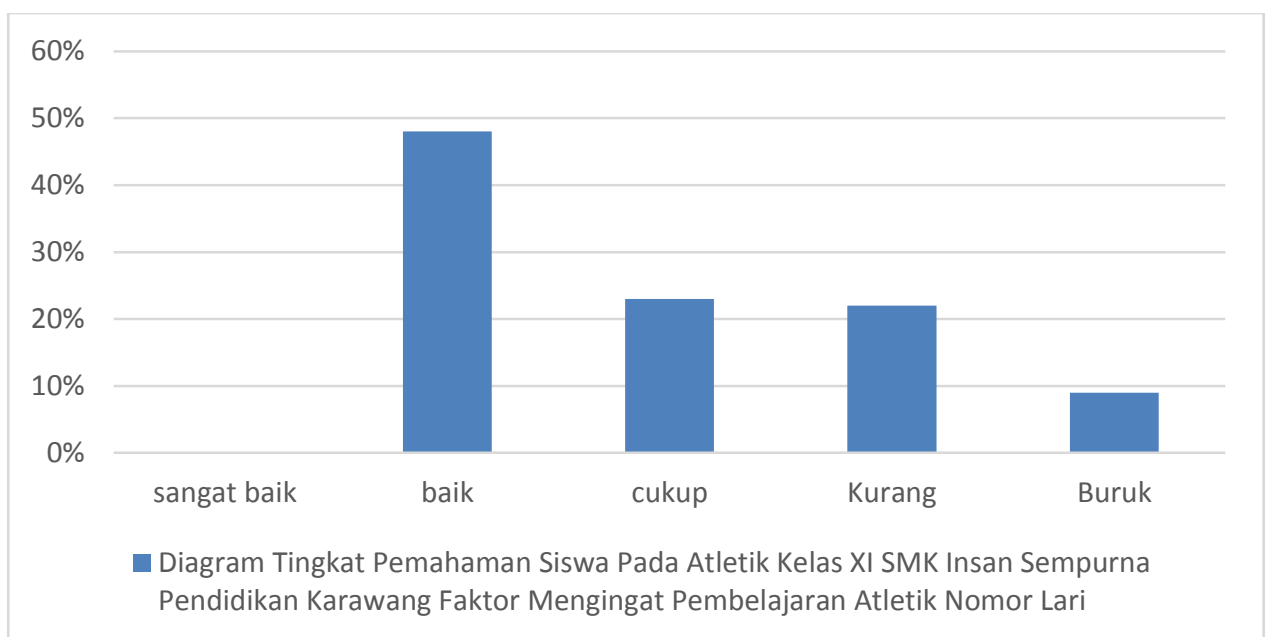

\section{Gambar 2. Diagram Batang Tingkat Pemahaman Siswa Pada Atletik Nomor Lari Kelas XI SMK Insan Sempurna Pendidikan Karawang Faktor Mengingat Pembelajaran Atletik Nomor Lari}

Dalam faktor mengingat pembelajaran atletik nomor lari, dipengaruhi oleh dua indikator, setelah dilakukannya perhitungan maka hasil statistik deskriptif dari indikator adalah sebagai berikut: 1) Indikator mengingat hakikat atletik yang berkategori cukup dengan jumlah 74 siswa (80\%). 2) Indikator mengingat macam macam atletik nomor lari yang berkategori baik dengan jumlah 31 siswa (34\%).

\section{Faktor Memahami Pembelajaran Atletik Nomor Lari}

Dalam instrument penelitian ini terdapat 2 indikator yaitu, memahami teknik lari dan memahami gerakan \& peraturan lari. Masing-masing indikator dijabarkan melalui beberapa butir pertanyaan, memahami teknik lari 7 pertanyaan, dan memahami gerakan \& peraturan lari 8 pertanyaan. Dalam 2 indikator dinyatakan semua pertanyaan valid sehingga layak digunakan untuk instrument penelitian. Berdasarkan hasil penelitian dari faktor mengingat pembelajaran atletik nomor lari diperoleh mean sebesar 81,70, standar deviasi sebesar 19,62, Range sebesar 83,33, median sebesar 83,33, nilai minimum 16,67 dan nilai maximum 100. Dapat dimasukan kedalam tabel distribusi frekuensi sebagai berikut.

\begin{tabular}{ccccccc}
\multicolumn{6}{c}{ Tabel 6. Distribusi Frekuensi Faktor Memahami Pembelajaran Atletik Nomor Lari } \\
\hline No & & Interval & & Kategori & Frekuensi & $\%$ \\
\hline 1 & & $\mathrm{X}>$ & 97.94 & Sangat Baik & 3 & $3 \%$ \\
2 & 75.64 & $<\mathrm{X}<$ & 97.94 & Baik & 28 & $30 \%$ \\
3 & 53.34 & $<\mathrm{X}<$ & 75.64 & Cukup & 28 & $30 \%$ \\
4 & 31.04 & $<\mathrm{X}<$ & 53.34 & Kurang & 27 & $29 \%$ \\
5 & & $\mathrm{X}<$ & 31.04 & Buruk & 6 & $7 \%$ \\
\hline
\end{tabular}

Berdasarkan tabel tersebut dapat dijelaskan bahwa secara faktor memahami pembelajaran atletik tingkat pemahaman siswa pada atletik nomor lari kelas xi smk insan sempurna pendidikan karawang berkategori "baik dan cukup" dikarenakan memiliki skor yang sama dengan jumlah 28 siswa (30\%). Apabila digambarkan dalam bentuk diagram batang diperoleh sebagai berikut.

Dipublikasikan Oleh : 


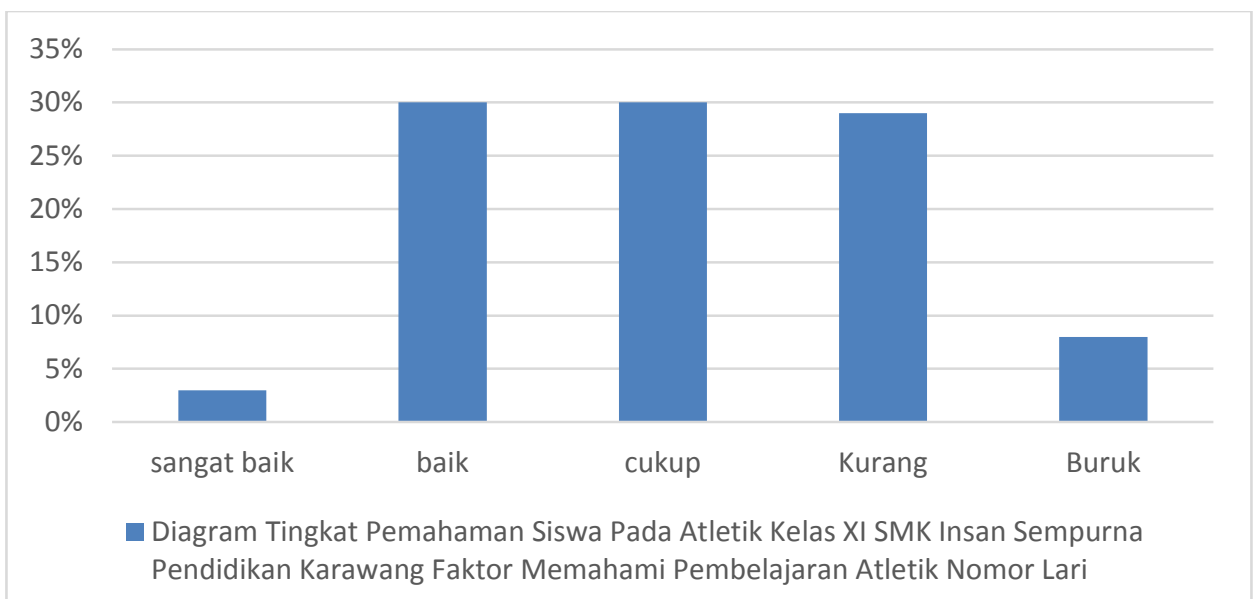

\section{Gambar 3. Diagram Batang Tingkat Pemahaman Siswa Pada Atletik Nomor Lari Kelas XI SMK Insan Sempurna Pendidikan Karawang Faktor Memahami Pembelajaran Atletik Nomor Lari}

Dalam faktor memahami pembelajaran atletik nomor lari, dipengaruhi oleh dua indikator, setelah dilakukannya perhitungan maka hasil statistik deskriptif dari indikator adalah sebagai berikut: 1) Indikator memahami teknik lari yang berkategori cukup dengan jumlah 35 siswa (38\%). 2) Indikator memahami gerakan dan peraturan lari yang berkategori cukup dengan jumlah 34 siswa $(37 \%)$.

Berdasarkan data yang diperoleh dapat tingkat pemahaman siswa pada atletik nomor lari kelas XI SMK Insan Sempurna Pendidikan Karawang berada pada kategori "sangat baik" sebesar 0\% (0 Siswa), kategori "baik" sebesar 35\% (32 Siswa), kategori "cukup" sebesar 36\% (33 Siswa), kategori "kurang" sebesar 21\% (19 Siswa), dan kategori "buruk" sebesar 9\% (8 Siswa), sehingga memperoleh nilai rata-rata yaitu 19,48 dari jumlah 30 butir soal. Jadi dapat di simpulkan bahwa secara keseluruhan tingkat pemahaman siswa pada atletik nomor lari kelas xi smk insan sempurna pendidikan karawang berada di kategori cukup. tingkat pemahaman siswa pada atletik nomor lari kelas XI SMK Insan Sempurna Pendidikan Karawang ini tidak jauh berbeda jika dibandingkan dengan penelitian terdahulu yang dilakukan oleh Zulfikar, (2019) "Tingkat Pengetahuan Siswa Kelas VIII Terhadap Pembelajaran Lari Jarak Pendek Di SMP Negeri 5 Depok Sleman Tahun Ajaran 2018/2019” Hasil penelitian menunjukkan bahwa tingkat pengetahuan siswa kelas VIII tentang pembelajaran lari jarak pendek di SMP Negeri 5 Depok Sleman tahun ajaran 2018/2019 yaitu sebanyak 92 siswa kategori baik (17,4 \%), kategori cukup $(66,3 \%)$, dan kategori kurang $(16,3 \%)$.

\section{PENUTUP}

Berdasarkan hasil penelitian dan pembahasan, maka dapat disimpulkan bahwa: pertama, tingkat pemahaman siswa pada atletik nomor lari kelas XI SMK Insan Sempurna Pendidikan Karawang secara keseluruhan adalah cukup. Kedua, tingkat pemahaman terhadap: 1) Faktor mengingat pembelajaran atletik nomor lari adalah baik, yang meliputi indikator, a) Mengingat hakikat atletik adalah cukup, b) indikator macammacam atletik nomor lari adalah baik, Dan. 2) Faktor memahami pembelajaran atletik nomor lari adalah baik \& cukup, yang meliputi indikator $\quad$ a) indikator memahami teknik lari adalah cukup.b) indikator memahami gerakan dan peraturan lari adalah cukup. Hasil penelitian ini diharapkan bisa meningkatkan kualitas pembelajaran mengenai aktivitas atletik khusunya nomor lari, pembuatan model pembelajaran dan praktik secara langsung untuk memperoleh hasil yang lebih optimal.

\section{REFERENSI}

\section{Buku}

Purnomo, \& Dapan. (2011). Dasar-dasar gerak atletik.

Rahayu, E. T. (2013). Strategi Belajar Mengajar Penjaskes. Depdikbud: Jakarta.

Sudijono, A. (2012). Pengantar Statistik. Raja Grafindo Persada, Jakarta.

Sugiyono, P. D. (2013). Statistik untuk Penelitian. CV. Alvabeta Bandung.

Syah, M. (2010). Psikologi pendidikan. Bandung: Remaja Rosdakarya, 10.

\section{Artikel Jurnal}

Dipublikasikan Oleh :

UPT Publikasi dan Pengelolaan Jurnal

Universitas Islam Kalimantan Muhammad Arsyad Al-Banjari Banjarmasin 
Achmad, I. Z., \& R, A. K. Y. (2013). Persepsi Mahasiswa Pjkr Pada Matakuliah Pembelajaran Permainan Bola Voli Di Universitas Singaperbangsa Karawang. Journal of Chemical Information and Modeling, 53(9), 1689-1699. https://doi.org/10.1017/CBO9781107415324.004

Arikunto, S. (2013). Prosedur penelitian atau pendekatan praktik. Cet XV, 86-251.

Bahagia, Y. (2011). Pembelajaran atletik. In Pembelajaran Atletik, Departemen Pendidikan Nasional.

Dwiyogo, W. D. (2010). Dimensi Teknologi Pembelajaran Pendidikan Jasmani dan Olahraga. Malang: Wineka Media.

Gunawan, A. P., Achmad, I. Z., \& Resita, C. (2020). Tingkat pemahaman aktivitas renang pada siswa. $156-169$. https://doi.org/10.31571/jpo.v9i2.1899

Hasan, S., Winarno, M. E., \& Tomi, A. (2015). Pengembangan Model Permainan Gerak Dasar Lempar Untuk Siswa Kelas V Sdn Tawangargo 4 Karangploso Malang. Jurnal Pendidikan Olahraga, 4(2), 182-200.

Muhtar, T. (2011). Atletik. UPI Sumedang Press.

Natal, Y. R. (2018). Manajemen Pembinaan Olahraga Atletik Lari Jarak Jauh 10 . 000 Meter Pada Persatuan Atletik Seluruh Indonesia ( Pasi ) Provinsi Nusa Tenggara Timur Tahun 2017. Jurnal Ilmiah Pendidikan Citra Bakti, 5(1), 15-23. https://abstrak.ta.uns.ac.id/wisuda/upload/A121408039_pendahuluan.pdf

Pahliwandari, R. (2016). Penerapan Teori Pembelajaran Kognitif dalam Pembelajaran Pendidikan Jasmani dan Kesehatan. Jurnal Pendidikan Olahraga, 5(2), 154-164.

Pambudi, M. I., Winarno, M., \& Dwiyogo, W. D. (2019). Perencanaan dan Pelaksanaan Pembelajaran Pendidikan Jasmani Olahraga Kesehatan. Jurnal Pendidikan Olahraga, Universitas Negeri Malang, 4(1), 110-116. http://journal.um.ac.id/index.php/jptpp/

Putro, D. E. (2019). Tingkat Pemahaman Guru Penjas Sekolah Menengah Atas Dan Kejuruan Se-Kabupaten Pacitan Terhadap Peraturan Permainan Futsal Tahun 2017. Journal of Chemical Information and Modeling, 53(9), 1689-1699. https://doi.org/10.1017/CBO9781107415324.004

Ulinnuha, A. (2017). Tingkat Pemahaman Aktivitas Renang Pada Siswa Level of Understanding of Swimming Activity on Eleventh Grade Students in Sman 1 Jogonalan Klaten. 1, 1-10.

Zulfikar Muhammad. (2019). Tingkat pengetahuan siswa kelas VIII terhadap pembelajaran lari jarak pendek di smp negeri 5 depok sleman tahun ajaran 2018/2019. NASPA Journal, 42(4), 1.

Dipublikasikan Oleh :

UPT Publikasi dan Pengelolaan Jurnal

Universitas Islam Kalimantan Muhammad Arsyad Al-Banjari Banjarmasin 